\title{
Effect of Secondary and Micronutrients on Growth Attributes and Yield of Elephant Foot Yam (Amorphophallus paeoniifolius)
}

\author{
Biswanath Sahoo ${ }^{*}$, M. Nedunchezhiyan ${ }^{2}$, P. Acharyya ${ }^{3}$, \\ R. Munshi ${ }^{3}$, D. Sahu ${ }^{4}$ and Rojalin Pradhan ${ }^{5}$
}

${ }^{1}$ Krishi Vigyan Kendra (OUAT), Ranital, Bhadrak, Odisha, India-756111

${ }^{2}$ Regional Centre of ICAR-Central Tuber Crops Research Institute, Bhubaneswar, Odisha, India-751019

${ }^{3}$ Department of Horticulture, University of Calcutta, Kolkata, West Bengal, India- 700019

${ }^{4}$ Department of Plant Breeding and Genetics, OUAT, Bhubaneswar, Odisha, India-751003

${ }^{5}$ Department of Vegetable Science, OUAT, Bhubaneswar-751003, India

*Corresponding author

\section{Ke y w o r d s \\ Elephant foot yam, Corm yield, Growth, Secondary and Micro nutrients \\ Article Info \\ Accepted: 04 April 2019 Available Online: 10 May 2019}

\section{A B S T R A C T}

A field experiment was conducted during 2012 and 2013 to assess the effect of secondary and micronutrients on growth and yield of elephant foot yam [Amorphophallus paeoniifolius (Dennst.) Nicolson] at the Regional Centre of ICAR-Central Tuber Crops Research Institute, Bhubaneswar, Odisha, India. The experiment was laid out in randomized block design with three replications. The experiment consisted of nine treatments viz. $\mathrm{T}_{1}$ - Control(no manure and fertilizer), $\mathrm{T}_{2}-\mathrm{FYM} @ 10 \mathrm{t} / \mathrm{ha}+\mathrm{N}-\mathrm{P}_{2} \mathrm{O}_{5}-\mathrm{K}_{2} \mathrm{O}$ @100-60-100 kg/ha, T 3 -FYM @ 10 t/ha+N-P $\mathrm{O}_{5}-\mathrm{K}_{2} \mathrm{O} @ 100-60-100$ kg/ha+ $\mathrm{MgSO}_{4} @ 20$ kg/ha, T $4^{-}$FYM @ 10 t/ha+N-P $\mathrm{O}_{5^{-}}-\mathrm{K}_{2} \mathrm{O} @ 100-60-100 \mathrm{~kg} / \mathrm{ha}+\mathrm{ZnSO}_{4} @ 10 \mathrm{~kg} / \mathrm{ha}, \mathrm{T}_{5}-$ FYM @10 t/ha+N-P $\mathrm{O}_{5}-\mathrm{K}_{2} \mathrm{O} @ 100-60-100$ kg/ha+Borax@10 kg/ha, T 6 - FYM @ 10 t/ha+N-P $\mathrm{O}_{5}-\mathrm{K}_{2} \mathrm{O} @ 100-60-100 \mathrm{~kg} / \mathrm{ha}+\mathrm{MgSO}_{4} @ 20 \mathrm{~kg} / \mathrm{ha}+\mathrm{ZnSO}_{4} @ 10 \mathrm{~kg} / \mathrm{ha}, \mathrm{T}_{7}-\mathrm{FYM}$ @10 t/ha+N-P $\mathrm{O}_{5}-\mathrm{K}_{2} \mathrm{O} @ 100-60-100 \mathrm{~kg} / \mathrm{ha}+\mathrm{MgSO}_{4} @ 20 \mathrm{~kg} / \mathrm{ha}+\mathrm{Borax} @ 10 \mathrm{~kg} / \mathrm{ha}, \mathrm{T}_{8}-$ FYM @10 t/ha+N-P $\mathrm{O}_{5}-\mathrm{K}_{2} \mathrm{O} @ 100-60-100$ kg/ha+ZnSO $\mathrm{Zn}_{4} @ 10$ kg/ha+Borax @10

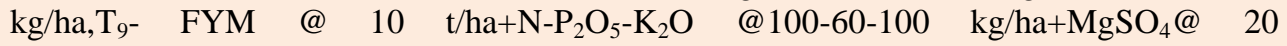
$\mathrm{kg} / \mathrm{ha}+\mathrm{ZnSO}_{4} @ 10 \mathrm{~kg} / \mathrm{ha}+\mathrm{Borax} @ 10 \mathrm{~kg} / \mathrm{ha}$. The results revealed that manures and fertilizers did not influence days to sprouting. The pseudostem height $(115.8 \mathrm{~cm})$, pseudostem diameter $(15.8 \mathrm{~cm})$, canopy spread $(109.11 \mathrm{~cm})$, number of leaflets per plant (337.5) and light interception percentage (76.74\%) were superior in $\mathrm{T}_{9}(\mathrm{FYM} @ 10 \mathrm{t} / \mathrm{ha}+\mathrm{N}-$ $\mathrm{P}_{2} \mathrm{O}_{5}-\mathrm{K}_{2} \mathrm{O} @ 100-60-100 \mathrm{~kg} / \mathrm{ha}+\mathrm{MgSO}_{4} @ 20 \mathrm{~kg} / \mathrm{ha}+\mathrm{ZnSO}_{4} @ 10 \mathrm{~kg} / \mathrm{ha}+\mathrm{Borax} @ 10$ $\mathrm{kg} / \mathrm{ha}$ )than rest of the treatments. The treatment $\mathrm{T}_{9}\left(\mathrm{FYM} @ 10 \mathrm{t} / \mathrm{ha}+\mathrm{N}-\mathrm{P}_{2} \mathrm{O}_{5}-\mathrm{K}_{2} \mathrm{O} @ 100-\right.$ 60-100 kg/ha+MgSO $\mathrm{Mg}_{4} 0 \mathrm{~kg} / \mathrm{ha}+\mathrm{ZnSO}_{4} @ 10 \mathrm{~kg} / \mathrm{ha}+$ Borax @10 kg/ha)resulted in lower soil resistance. The corm diameter $(25.9 \mathrm{~cm})$, corm yield/plant $\left(2375 \mathrm{~g} \mathrm{plant}^{-1}\right)$ and corm yield (42.2 $\mathrm{t} \mathrm{ha}^{-1}$ ) were greater in $\mathrm{T}_{9}\left(\mathrm{FYM} @ 10 \mathrm{t} / \mathrm{ha}+\mathrm{N}-\mathrm{P}_{2} \mathrm{O}_{5}-\mathrm{K}_{2} \mathrm{O}\right.$ @ 100-60-100 kg/ha+ $\mathrm{MgSO}_{4} @ 20$ kg/ha+ZnSO ${ }_{4} @ 10$ kg/ha+Borax @10 kg/ha).The lowest growth and yield attributes, and yield were recorded in $\mathrm{T}_{1}$ (control). 


\section{Introduction}

Elephant foot yam (Amorphophallus paeoniifolius (Dennst.) Nicolson), a tuberous vegetable crop is gaining importance as commercial crop due to its unprecedented productivity (50 t/ha) and long storability (3-5 months) (Nedunchezhiyan, 2014). The corms (tubers) are consumed as vegetable after boiling, baking and frying (Nedunchezhiyan et al., 2002; Nedunchezhiyan et al., 2006). Young leaves are also used as vegetable after chopping and boiling (Nedunchezhiyan, 2014). Flowers are also used as food (Raghu et al., 1999). Pickle, a delicacy recipe preferred by Indians is also prepared from elephant foot yam corms (Nedunchezhiyan and Misra, 2008). The corms are rich in minerals and vitamins (Nedunchezhiyan et al., 2008). Elephant foot yam corm is a good remedy for patients suffering from piles, asthma, dysentery and abdominal pain (Misra et al., 2002).

Elephant foot yam removes huge quantity of nutrients. Kabeerathumma et al., (1987) reported that a crop yielding 33 tonnes of corms removed $128.8 \mathrm{~kg} \mathrm{~N}, 23.6 \mathrm{~kg} \mathrm{P}, 239.6$ $\mathrm{kg} \mathrm{K}$ and $0.490 \mathrm{~kg} \mathrm{Zn}$ per ha. Nair et al., (1990) observed that a crop yielding 43 tonnes of corm would remove $124.8 \mathrm{~kg} \mathrm{~N}$, $25.1 \mathrm{~kg} \mathrm{P}$ and $224.4 \mathrm{~kg} \mathrm{~K}$ per ha. Elephant foot yam responds well to application of manures and fertilizers. External application of not only macro nutrients but also micro nutrients is essential for achieving higher yield in elephant foot yam. Magnesium $(\mathrm{Mg})$, Zinc (Zn) and Boron (B) deficiency have been aggravated in the soil due to its continuous removal under intensive cropping. Magnesium is a constituent of chlorophyll, essential for photosynthesis (Chauhan et al., 2014). It is also an activator of many enzymes and takes part in protein synthesis. The absorption and utilization of $\mathrm{Mg}$ increased with age of the crop. However, Mg utilization was higher during tuber bulking stage Kabeerathumma et al., (1987). Zinc is regarded as the third most important limiting nutrient element in crop production after $\mathrm{N}$ and $\mathrm{P}$ (Gupta, 1995).It is now considered an important yield raising input, which in principle and practice is a part of balanced fertilizer use. Zinc is an essential constituent of ribosomes and is associated with the activity of tryptophane synthates enzyme (Chauhan et al., 2014). Boron is one of the essential micronutrients required for the normal growth and development of plants. Boron is needed for the development and differentiation of tissues particularly growing tips, phloem and xylem (Sakal and Singh, 1995). Alfisols are mostly deficient in major nutrients like nitrogen, phosphorus and potassium and minor nutrients like zinc, magnesium and boron. In our earlier study found that FYM @10 t/ha+N- $-\mathrm{P}_{2} \mathrm{O}_{5}-\mathrm{K}_{2} \mathrm{O} @$ $100-60-100 \mathrm{~kg} / \mathrm{ha}$ was optimum for elephant foot yam under alfisols (Sahoo et al., 2015). Hence, the present study was carried out to find the effects of secondary and micronutrients along with recommended major nutrients on elephant foot yam growth and yield.

\section{Materials and Methods}

A field experiment was conducted during 2012 and 2013at the Regional Centre of Central Tuber crops Research Institute $\left(20^{\circ} 14^{\prime} 53.25^{\prime \prime} \mathrm{N}\right.$ and $85^{\circ} 47^{\prime} 25.85^{\prime \prime} \mathrm{E}$ and $33 \mathrm{~m}$ above mean sea level), Dumuduma, Bhubaneswar, Odisha, India situated in the East and South Eastern Central Coastal Plain Zone of Odisha. The soil type of experimental site was alfisols and falls under the family on Typic Rhodustalfs. Texturally the soil was sandy loam with $\mathrm{p}^{\mathrm{H}} 6.5$, organic carbon $0.32 \%$, available nitrogen $98.2 \mathrm{~kg} / \mathrm{ha}$, available phosphorus $16.2 \mathrm{~kg} / \mathrm{ha}$, available potassium $242.4 \mathrm{~kg} / \mathrm{ha}$, available magnesium $1562 \mathrm{ppm}$, available zinc $1.46 \mathrm{ppm}$ and 
available boron $1.03 \mathrm{ppm}$. The experiment was laid out in randomized block design (RBD) with three replications. The experiment consisted of nine treatments viz. $\mathrm{T}_{1^{-}}$Control (no manure and fertilizer), $\mathrm{T}_{2^{-}}$ FYM @ 10 t/ha+N-P $\mathrm{O}_{5}-\mathrm{K}_{2} \mathrm{O}$ @ 100-60-100 $\mathrm{kg} / \mathrm{ha}, \quad \mathrm{T}_{3}-\mathrm{FYM}$ @ 10 t/ha+N-P $\mathrm{O}_{5}-\mathrm{K}_{2} \mathrm{O}$ @100-60-100 kg/ha+MgSO 4 @ 20 kg/ha, T4FYM@10 t/ha+N-P $\mathrm{P}_{2} \mathrm{O}_{5}-\mathrm{K}_{2} \mathrm{O} @ 100-60-100$ $\mathrm{kg} / \mathrm{ha}+\mathrm{ZnSO}_{4} @ 10 \mathrm{~kg} / \mathrm{ha}, \mathrm{T}_{5}-\mathrm{FYM} @ 10$ t/ha+N-P $\mathrm{O}_{5}-\mathrm{K}_{2} \mathrm{O} @ 100-60-100$ kg/ha+Borax @10 kg/ha, T6 - FYM @ 10 t/ha+N-P ${ }_{2} \mathrm{O}_{5^{-}}$ $\mathrm{K}_{2} \mathrm{O}$ @100-60-100 kg/ha+ $\mathrm{MgSO}_{4} @ 20$ $\mathrm{kg} / \mathrm{ha}+\mathrm{ZnSO}_{4} @ 10 \mathrm{~kg} / \mathrm{ha}, \mathrm{T}_{7^{-}}$FYM @10 $\mathrm{t} / \mathrm{ha}+\mathrm{N}-\mathrm{P}_{2} \mathrm{O}_{5}-\mathrm{K}_{2} \mathrm{O} @ 100-60-100 \quad \mathrm{~kg} / \mathrm{ha}$ $+\mathrm{MgSO}_{4} @ 20 \mathrm{~kg} / \mathrm{ha}+$ Borax @10 kg/ha, T ${ }_{8}$ FYM @ 10 t/ha+N-P $\mathrm{O}_{5}-\mathrm{K}_{2} \mathrm{O} @ 100-60-100$ kg/ha+ZnSO 4 @10 kg/ha+Borax @10 kg/ha, T9- FYM @10 t/ha+N- $\mathrm{P}_{2} \mathrm{O}_{5}-\mathrm{K}_{2} \mathrm{O} @ 100-60$ 100 kg/ha+ $\mathrm{MgSO}_{4} @ 20 \mathrm{~kg} / \mathrm{ha}+\mathrm{ZnSO}_{4} @ 10$ kg/ha+Borax @10 kg/ha. Sahoo et al., (2015) recommended FYM @ 10 t/ha+ $\mathrm{N}-\mathrm{P}_{2} \mathrm{O}_{5}-\mathrm{K}_{2} \mathrm{O}$ ( 100-60-100 kg/ha for elephant foot yam under alfisols.

FYM and full dose of $\mathrm{P}_{2} \mathrm{O}_{5}$ were applied during final ploughing. Full dose of $\mathrm{MgSO}_{4}$, $\mathrm{ZnSO}_{4}$ and Borax, and $1 / 3^{\text {rd }}$ of $\mathrm{N}$ and $\mathrm{K}$ were applied before ridge making as basal. The remaining $2 / 3^{\text {rd }}$ of $\mathrm{N}$ and $\mathrm{K}$ was split in to two equal doses and applied at $1^{\text {st }}$ and $2^{\text {nd }}$ month after planting (MAP). The ridges were made at $75 \mathrm{~cm}$ spacing. Elephant foot yam variety 'Gajendra' was selected for planting. The corm weighing $400 \mathrm{~g}$ was planted on the ridges at $75 \mathrm{~cm}$ spacing. Thus, a spacing of $75 \times 75 \mathrm{~cm}$ between row-to-row and plant-toplant was maintained. Three hand weeding was carried out at $1^{\text {st }}, 2^{\text {nd }}$ and $3^{\text {rd }}$ MAP. The crop was raised under protective drip irrigation. The crop was harvested at $8^{\text {th }}$ MAP. During 2012 and 2013, the average mean monthly maximum and minimum temperatures ranged $29.4-38.3^{\circ} \mathrm{C}$ and $15.4-$ $26.6^{\circ} \mathrm{C}$, respectively and mean monthly relative humidity ranged $61.5-90.7 \%$. The average annual rainfall was $1254.7 \mathrm{~mm}$ and maximum precipitation was received during June to September.

Growth attributes (height and diameter of pseudostem, canopy spread and number of leaflets per plant) were measured at $3^{\text {rd }}$ and $5^{\text {th }}$ MAP. Light interception (\%) at canopy was computed at 3 and 5 MAP. Light measurements above and below canopy were measured with digital light meter LX-101A, Lutron Electronic Enterprise Co., Ltd). The difference of light measurement above and below canopy was multiplied with 100 and expressed in percentage of light interception. Soil resistance was measured with penetrologger (Eijkelkamp, The Netherlands) at 3 and 5 MAP and expressed in MPa. Corm yield was recorded at $8^{\text {th }}$ MAP (harvest). The data were subjected to the analysis of variance (ANOVA) in randomized block design using GENSTAT programme. The significant differences between the treatments were compared with the critical difference (CD) at a $5 \%$ level of probability

\section{Results and Discussion}

\section{Growth}

The perusal of data (Table 1) on the days to attainment of 50 and $100 \%$ sprouting of elephant foot yam cv. Gajendra revealed that manures and fertilizers had no effect on sprouting. Application of FYM, N, P, K, Mg, $\mathrm{Zn}$ and Bin various combinations resulted no particular trend for days to $50 \%$ sprouting and non-significant trend for days to $100 \%$ sprouting. In elephant foot yam, days to sprouting is depend on maturity of the corm, dormancy, type of corm (whole/cut), weight of corm sett, soil moisture status and prevailing weather conditions.

Elephant foot yam produces crown shaped crop canopy on the pseudostem (Nedunchezhiyan, 2014) and it looks like an umbrella. During the crop growth period, 
usually it produces on an average 2-3 pseudostems (leaves) per plant (Nedunchezhiyan et al., 2017). Sometime produces multiple pseudostem when cut corms are used due to activation of dormant buds. At $3^{\text {rd }}$ and $5^{\text {th }}$ MAP, the growth attributes were recorded on $1^{\text {st }}$ and $2^{\text {nd }}$ pseudostem, respectively as suggested by Nedunchezhiyan et al., (2016).

Marked variation in pseudostem height and diameter, canopy spread and number of leaflets per plant was noticed at $3^{\text {rd }}$ and $5^{\text {th }}$ MAP with respect to treatments (Table 1). The treatment $\mathrm{T}_{9}\left(\mathrm{FYM} @ 10 \mathrm{t} / \mathrm{ha}+\mathrm{N}-\mathrm{P}_{2} \mathrm{O}_{5^{-}}\right.$ $\mathrm{K}_{2} \mathrm{O} @ 100-60-100 \mathrm{~kg} / \mathrm{ha}+\mathrm{MgSO}_{4}$ @ 20 $\mathrm{kg} / \mathrm{ha}+\mathrm{ZnSO}_{4} @ 10 \mathrm{~kg} / \mathrm{ha}+$ Borax @ 10 $\mathrm{kg} / \mathrm{ha}$ )resulted in taller pseudostem, greater pseudostem diameter, canopy spread and number of leaves per plant at $3^{\text {rd }}$ and $5^{\text {th }}$ MAP.

It was followed by $\mathrm{T}_{8}(\mathrm{FYM} @ 10 \mathrm{t} / \mathrm{ha}+\mathrm{N}$ $\mathrm{P}_{2} \mathrm{O}_{5}-\mathrm{K}_{2} \mathrm{O} @ 100-60-100 \mathrm{~kg} / \mathrm{ha}+\mathrm{ZnSO}_{4} @ 10$ kg/ha+Borax@10 kg/ha). Application of Mg, $\mathrm{Zn}$ and $\mathrm{B}$ nutrients either alone or in combinations with recommended dose of manures and fertilizers (FYM @ $10 \mathrm{t} / \mathrm{ha}+\mathrm{N}$ $\mathrm{P}_{2} \mathrm{O}_{5}-\mathrm{K}_{2} \mathrm{O} @ 100-60-100 \mathrm{~kg} / \mathrm{ha}$ ) resulted in greater growth attributes (pseudostem height and diameter, canopy spread and number of leaflets per plant) than application of recommended dose of manures and fertilizers alone (FYM @ 10 t/ha+N-P $\mathrm{P}_{5}-\mathrm{K}_{2} \mathrm{O} @ 100-$ $60-100 \mathrm{~kg} / \mathrm{ha})\left(\mathrm{T}_{2}\right)$ and control $\left(\mathrm{T}_{1}\right)$ (Table 1$)$.

Magnesium is the chief constituent of chlorophyll which resulted in the formation of carbohydrate in the leaves. The nutrients $\mathrm{Zn}$ and $\mathrm{B}$ are essential for cell division and enlargement, and various enzyme production and activation. Application of these nutrients increased cell division and multiplication, and carbohydrate accumulation thereby greater growth attributes. The results obtained were in accordance with Kabeerathumma et al., (1987).

\section{Light interception and soil resistance}

Light interception through the canopy system was significantly influenced by $\mathrm{Mg}, \mathrm{Zn}$ and $\mathrm{B}$ application in elephant foot yam (Table 2). At $3^{\text {rd }}$ and $5^{\text {th }}$ MAP, significantly greater light interception was measured when the plots were applied with FYM @ 10 t/ha+N- $\mathrm{P}_{2} \mathrm{O}_{5^{-}}$ $\mathrm{K}_{2} \mathrm{O} @ 100-60-100 \mathrm{~kg} / \mathrm{ha}+\mathrm{MgSO}_{4} @ 20$ kg/ha+ZnSO ${ }_{4} @ 10$ kg/ha+Borax@10 kg/ha. The superior light interception in this treatment was due to greater number of leaflets per plant (Table 1) which might have been led to larger LAI. Higher light interception led to higher photosynthesis and corm yield. Sahoo et al., (2014) also reported higher light interception in the treatment which received greater quantity of manures and fertilizers in elephant foot yam. The lowest light interception was recorded in the treatment control plots. This might be due to poor canopy development.

Soil resistance play significant role in tuber bulking. Soil resistance recorded at $3^{\text {rd }}$ and $5^{\text {th }}$ MAP revealed that lower soil resistance when combination of $\mathrm{Mg}, \mathrm{Zn}$ and $\mathrm{B}$ were applied along with recommended dose of FYM @ $10 \mathrm{t} / \mathrm{ha}+\mathrm{N}-\mathrm{P}_{2} \mathrm{O}_{5}-\mathrm{K}_{2} \mathrm{O} @ 100-60-100 \mathrm{~kg} / \mathrm{ha}\left(\mathrm{T}_{9}\right)$ (Table 2). This indicated that roots were active and occupies more volume of soil when applied required quantity of $\mathrm{Mg}, \mathrm{Zn}$ and $\mathrm{B}$ nutrients along with recommended dose of FYM @ 10t/ha+N-P ${ }_{2} \mathrm{O}_{5}-\mathrm{K}_{2} \mathrm{O} @ 100-60-100$ $\mathrm{kg} / \mathrm{ha}$. Nedunchezhiyan et al., (2013) reported that lower soil resistance in FYM and paddy straw applied sweet potato fields. In elephant foot yam, lower soil resistance was recorded when greater quantity of manures and fertilizers were applied (Sahoo et al., 2014).

\section{Yield}

Elephant foot yam corm diameter was profoundly influenced by treatments (Table $2)$. The treatment $\mathrm{T}_{9}(\mathrm{FYM} @ 10 \mathrm{t} / \mathrm{ha}+\mathrm{N}-$ 
$\mathrm{P}_{2} \mathrm{O}_{5}-\mathrm{K}_{2} \mathrm{O} @ 100-60-100 \mathrm{~kg} / \mathrm{ha}+\mathrm{MgSO}_{4} @ 20$ kg/ha+ZnSO ${ }_{4} @ 10$ kg/ha+Borax @10 kg/ha) resulted in greater corm diameter. However, it was statistically at par with $\mathrm{T}_{8}, \mathrm{~T}_{7}, \mathrm{~T}_{6}, \mathrm{~T}_{5}, \mathrm{~T}_{4}$, $\mathrm{T}_{3}$ and $\mathrm{T}_{2}$. Significantly lower corm diameter was noticed in control treatment. Marked variation in corm yield per plant was observed with respect to treatments. The treatment $\mathrm{T}_{9}$ (FYM @ $10 \mathrm{t} / \mathrm{ha}+\mathrm{N}-\mathrm{P}_{2} \mathrm{O}_{5}-\mathrm{K}_{2} \mathrm{O} @ 100-60-$ $100 \mathrm{~kg} / \mathrm{ha}+\mathrm{MgSO}_{4} @ 20 \mathrm{~kg} / \mathrm{ha}+\mathrm{ZnSO}_{4} @ 10$ $\mathrm{kg} / \mathrm{ha}+$ Borax @ $10 \mathrm{~kg} / \mathrm{ha}$ ) resulted in greater corm yield/plant. However, it was statistically at par with $\mathrm{T}_{8}, \mathrm{~T}_{7}, \mathrm{~T}_{6}, \mathrm{~T}_{5}, \mathrm{~T}_{4}$ and $\mathrm{T}_{3}$. This was due to greater growth (Table 1) and yield attributes (Table 2). Significantly lower corm yield/plant was noticed in control treatment. Discerning difference in corm yield was observed with respect to treatments (Table 2). The treatment $\mathrm{T}_{9}$ (FYM @ $10 \mathrm{t} / \mathrm{ha}+\mathrm{N}-\mathrm{P}_{2} \mathrm{O}_{5^{-}}$ $\mathrm{K}_{2} \mathrm{O}$ @ 100-60-100 kg/ha+ $\mathrm{MgSO}_{4}$ @ 20 kg/ha+ZnSO ${ }_{4} @ 10$ kg/ha+Borax@10 kg/ha) resulted in greater corm yield. However, it was statistically at par with $\mathrm{T}_{8}, \mathrm{~T}_{7}, \mathrm{~T}_{6}, \mathrm{~T}_{5}, \mathrm{~T}_{4}$ and $\mathrm{T}_{3}$. The higher corm yield in these treatments was due to higher growth (Table 1) and yield attributes (Table 2). The treatment $\mathrm{T}_{9}$ (FYM @ 10 t/ha+N-P $\mathrm{P}_{2} \mathrm{O}_{5}-\mathrm{K}_{2} \mathrm{O} @ 100-60-$ $100 \mathrm{~kg} / \mathrm{ha}+\mathrm{MgSO}_{4} @ 20 \mathrm{~kg} / \mathrm{ha}+\mathrm{ZnSO}_{4} @ 10$ $\mathrm{kg} / \mathrm{ha}+$ Borax @10 kg/ha) produced $7.7 \%$ greater corm yield than $\mathrm{T}_{2}$ (FYM @ 10 $\left.\mathrm{t} / \mathrm{ha}+\mathrm{N}-\mathrm{P}_{2} \mathrm{O}_{5}-\mathrm{K}_{2} \mathrm{O} @ 100-60-100 \mathrm{~kg} / \mathrm{ha}\right)$ (Table 2). Individual application of $\mathrm{Mg}, \mathrm{Zn}$ and $\mathrm{B}$ has increased corm yield 2.3-3.3\%. This showed that under present experimental site, the elephant foot yam response to $\mathrm{Mg}$, $\mathrm{Zn}$ and $\mathrm{B}$ is very less. However, combined application of all the above nutrients had the additive effect of $7.7 \%$ greater corm yield. The greater photosynthates accumulated in the shoot (source) was translocated to the bulking corm (sink). Kabeerathumma et al., (1987) reported that Mg utilization was higher during tuber bulking stage, as it is essential for carbohydrate synthesis. Singh and Pathak (2002), and Chauhan et al., (2014) also reported similar findings.

Table.1 Effect of Mg, Zn and B nutrients on growth attributes elephant foot yam cv. Gajendra (pooled data of 2 years)

\begin{tabular}{|c|c|c|c|c|c|c|c|c|c|c|}
\hline \multirow{2}{*}{$\begin{array}{l}\text { Trea } \\
\text { tmen } \\
\mathrm{t}\end{array}$} & \multirow{2}{*}{$\begin{array}{l}\text { Days to } \\
50 \% \\
\text { sprouting }\end{array}$} & \multirow{2}{*}{$\begin{array}{l}\text { Days to } \\
100 \% \\
\text { sprouting }\end{array}$} & \multicolumn{2}{|c|}{$\begin{array}{l}\text { Pseudostem height } \\
(\mathrm{cm})\end{array}$} & \multicolumn{2}{|c|}{$\begin{array}{l}\text { Pseudostem } \\
\text { diameter }(\mathrm{cm})\end{array}$} & \multicolumn{2}{|c|}{$\begin{array}{l}\text { Canopy spread } \\
(\mathrm{cm})\end{array}$} & \multicolumn{2}{|c|}{$\begin{array}{l}\text { Number of leaflets } \\
\text { per plant }\end{array}$} \\
\hline & & & 3 -MAP & 5 MAP & 3 МАP & 5 MAP & 3 MAP & 5 MAP & 3 МАP & 5 MAP \\
\hline $\mathbf{T}_{1}$ & 28.00 & 36.33 & 23.9 & 51.9 & 4.90 & 11.6 & 40.04 & 94.43 & 136.5 & 225.0 \\
\hline $\mathbf{T}_{2}$ & 27.43 & 37.42 & 39.9 & 77.9 & 6.95 & 12.4 & 43.49 & 102.18 & 172.5 & 261.5 \\
\hline $\mathbf{T}_{\mathbf{3}}$ & 26.81 & 36.45 & 41.4 & 101.1 & 7.30 & 12.7 & 45.11 & 101.90 & 166.5 & 264.5 \\
\hline $\mathbf{T}_{4}$ & 26.19 & 36.53 & 41.8 & 101.8 & 7.40 & 13.2 & 44.93 & 101.80 & 167.5 & 262.5 \\
\hline $\mathbf{T}_{5}$ & 25.83 & 36.81 & 43.1 & 103.1 & 7.75 & 13.9 & 45.44 & 106.50 & 166.5 & 263.5 \\
\hline$T_{6}$ & 26.18 & 36.21 & 44.3 & 104.4 & 8.30 & 14.4 & 45.20 & 106.29 & 168.0 & 281.0 \\
\hline $\mathbf{T}_{7}$ & 25.04 & 36.45 & 48.9 & 107.2 & 8.70 & 14.9 & 45.02 & 106.22 & 169.5 & 247.5 \\
\hline $\mathbf{T}_{8}$ & 22.80 & 36.02 & 51.5 & 109.9 & 9.20 & 15.4 & 45.42 & 108.19 & 177.0 & 298.5 \\
\hline $\mathbf{T}_{9}$ & 28.11 & 35.61 & 55.5 & 115.8 & 9.80 & 15.8 & 45.89 & 109.11 & 180.0 & 337.5 \\
\hline $\begin{array}{c}\mathrm{SE} \\
\mathrm{m} \pm\end{array}$ & 0.407 & 0.866 & 1.47 & 3.64 & 0.37 & 0.52 & 1.56 & 3.64 & 6.68 & 10.04 \\
\hline $\begin{array}{c}\text { CD } \\
(0.05 \\
)\end{array}$ & 0.86 & NS & 3.1 & 7.7 & 0.8 & 1.1 & 3.3 & 7.7 & 14.1 & 21.2 \\
\hline
\end{tabular}


Table.2 Effect of $\mathrm{Mg}, \mathrm{Zn}$ and B nutrients on light interception, soil resistance, yield attributes and yield of elephant foot yam cv. Gajendra (pooled data of 2 years)

\begin{tabular}{|c|c|c|c|c|c|c|c|}
\hline \multirow[t]{2}{*}{ Treatment } & \multicolumn{2}{|c|}{$\begin{array}{c}\text { Light interception } \\
(\%)\end{array}$} & \multicolumn{2}{|c|}{$\begin{array}{l}\text { Soil resistance } \\
\text { (MPa) }\end{array}$} & \multirow{2}{*}{$\begin{array}{l}\text { Corm } \\
\text { diameter } \\
\text { (cm) }\end{array}$} & \multirow[t]{2}{*}{$\begin{array}{l}\text { Corm yield } \\
\text { (g/plant) }\end{array}$} & \multirow{2}{*}{$\begin{array}{l}\text { Corm } \\
\text { yield } \\
\text { (t/ha) }\end{array}$} \\
\hline & 3 MAP & 5 MAP & 3 MAP & 5 MAP & & & \\
\hline $\mathbf{T}_{1}$ & 22.10 & 48.84 & 0.399 & 0.353 & 19.9 & 990 & 17.6 \\
\hline $\mathbf{T}_{2}$ & 24.55 & 51.79 & 0.421 & 0.348 & 24.2 & 2210 & 39.2 \\
\hline $\mathbf{T}_{\mathbf{3}}$ & 20.81 & 64.80 & 0.416 & 0.368 & 24.0 & 2278 & 40.5 \\
\hline $\mathbf{T}_{4}$ & 53.63 & 58.65 & 0.388 & 0.381 & 24.0 & 2266 & 40.1 \\
\hline $\mathbf{T}_{5}$ & 46.08 & 61.53 & 0.351 & 0.303 & 24.7 & 2270 & 40.3 \\
\hline $\mathbf{T}_{6}$ & 47.28 & 63.85 & 0.338 & 0.309 & 24.8 & 2338 & 41.5 \\
\hline $\mathbf{T}_{7}$ & 54.18 & 67.46 & 0.331 & 0.264 & 25.4 & 2340 & 41.6 \\
\hline $\mathbf{T}_{8}$ & 57.33 & 67.25 & 0.289 & 0.233 & 25.4 & 2355 & 41.8 \\
\hline $\mathbf{T}_{9}$ & 61.05 & 76.74 & 0.305 & 0.241 & 25.9 & 2375 & 42.2 \\
\hline SEm \pm & 1.668 & 1.549 & 0.029 & 0.039 & 1.04 & 56.87 & 1.32 \\
\hline CD (0.05) & 3.52 & 3.27 & 0.062 & 0.084 & 2.2 & 120 & 2.8 \\
\hline
\end{tabular}

Table.3 Cost benefit analysis of experiment 2

\begin{tabular}{|c|c|c|c|c|}
\hline Treatments & Cost of cultivation & Gross return & Net return & B:C ratio \\
\hline $\mathbf{T}_{\mathbf{1}}$ & $1,57,800$ & $1,76,000$ & 18,200 & 1.11 \\
\hline $\mathbf{T}_{\mathbf{2}}$ & $1,88,720$ & $3,92,000$ & $2,03,280$ & 2.07 \\
\hline $\mathbf{T}_{\mathbf{3}}$ & $1,90,770$ & $4,05,000$ & $2,14,320$ & 2.12 \\
\hline $\mathbf{T}_{\mathbf{4}}$ & $1,89,870$ & $4,01,000$ & $2,11,130$ & 2.11 \\
\hline $\mathbf{T}_{\mathbf{5}}$ & $1,90,470$ & $4,03,000$ & $2,12,530$ & 2.11 \\
\hline $\mathbf{T}_{\mathbf{6}}$ & $1,91,970$ & $4,15,000$ & $2,23,030$ & 2.16 \\
\hline $\mathbf{T}_{\mathbf{7}}$ & $1,92,520$ & $4,16,000$ & $2,23,480$ & 2.16 \\
\hline $\mathbf{T}_{\mathbf{8}}$ & $1,91,920$ & $4,18,000$ & $2,26,080$ & 2.17 \\
\hline $\mathbf{T}_{\mathbf{9}}$ & $1,93,520$ & $4,22,000$ & $2,28,480$ & 2.18 \\
\hline $\mathbf{S E m} \mathbf{\pm}$ & 8967 & 18985 & 9540 & 0.076 \\
\hline $\mathbf{C D}(\mathbf{5} \%)$ & 18920 & 40060 & 20130 & 0.16 \\
\hline
\end{tabular}

The treatments $\mathrm{T}_{9}\left(\mathrm{FYM} @ 10 \mathrm{t} \mathrm{ha}^{-1}+\mathrm{N}^{-} \mathrm{P}_{2} \mathrm{O}_{5^{-}}\right.$ $\mathrm{K}_{2} \mathrm{O} @ 100-60-100 \mathrm{~kg} \mathrm{ha}^{-1}+\mathrm{MgSO}_{4} @ 20 \mathrm{~kg}$ $\mathrm{ha}^{-1}+\mathrm{ZnSO}_{4} @ 10 \mathrm{~kg} \mathrm{ha}^{-1}+$ Borax @10 kg $\mathrm{ha}^{-1}$ ) and $\mathrm{T}_{2}$ (FYM @ $10 \mathrm{t} \mathrm{ha}^{-1}+\mathrm{N}_{-} \mathrm{P}_{2} \mathrm{O}_{5}-\mathrm{K}_{2} \mathrm{O}$ @ 100-60-100 $\mathrm{kg} \mathrm{ha}^{-1}$ ) resulted in 139.8 and $122.7 \%$ greater corm yield, respectively than control (Table 2). The lower corm yield in control treatment was due to less availability of major nutrients ( $\mathrm{N}, \mathrm{P}$ and $\mathrm{K}$ ), secondary $(\mathrm{Mg})$ and minor ( $\mathrm{Zn}$ and $\mathrm{B})$ nutrients to the plants in the rhizosphere.
In the present study, it can be concluded that combined application of $\mathrm{MgSO}_{4}$ @ 20 kg/ha+ZnSO ${ }_{4} @ 10$ kg/ha+Boron@10 kg/ha along with FYM @10 t/ha+ $\mathrm{N}_{-} \mathrm{P}_{2} \mathrm{O}_{5}-\mathrm{K}_{2} \mathrm{O}$ @ 100-60-100 kg/ha was essential toget greater corm yield under alfisols.

\section{Economics}

The perusal of Table 3 indicated that cost of cultivation, gross return, net return and 
benefit cost ratio varied with the treatment. The cost of cultivation was found highest in $\mathrm{T}_{9}$ followed by $\mathrm{T}_{7}$ and the lowest was observed in $T_{1}$. The variation in cost of cultivation was due to inclusion of various micronutrients and their combinations. The higher gross and net returns were noticed in $\mathrm{T}_{9}$ followed by $\mathrm{T}_{8}$. This was due to higher yield in these treatments. Benefit cost ratio also followed by the similar trends. The highest being observed in $\mathrm{T}_{9}$.

In conclusion, the second phase of experiment 'Effect of secondary and micro nutrients' revealed that application of FYM @ $10 \mathrm{t} \mathrm{ha}^{-1}+$ $\mathrm{N}-\mathrm{P}_{2} \mathrm{O}_{5}-\mathrm{K}_{2} \mathrm{O} @ 100-60-100 \mathrm{~kg} \mathrm{ha}^{-1}$ along with $\mathrm{MgSO}_{4}\left(20 \mathrm{~kg} \mathrm{ha}^{-1}\right)+\mathrm{ZnSO}_{4}\left(10 \mathrm{~kg} \mathrm{ha}^{-1}\right)$ + Boron $\left(10 \mathrm{~kg} \mathrm{ha}^{-1}\right)$ increased the pseudostem height, canopy spread, number of leaflets/plant and maximum dry matter accumulation, corm yield $\left(42.2 \mathrm{t} \mathrm{ha}^{-1}\right)$ and soil enzyme activities. Qualitative parameters were also found higher in the above treatment. Macro, secondary and micronutrients helps in biofortification and bioavailability of these nutrients in elephant foot yam. Hence, FYM @ $10 \mathrm{tha}^{-1}+\mathrm{N}-\mathrm{P}_{2} \mathrm{O}_{5^{-}}$ $\mathrm{K}_{2} \mathrm{O} @ 100-60-100 \mathrm{~kg} \mathrm{ha}^{-1}+\mathrm{MgSO}_{4}(20 \mathrm{~kg}$ $\left.\mathrm{ha}^{-1}\right)+\mathrm{ZnSO}_{4}\left(10 \mathrm{~kg} \mathrm{ha}^{-1}\right)+$ Boron $(10 \mathrm{~kg} \mathrm{ha}$ ${ }^{1}$ ) can be recommended for elephant foot yam production.

\section{Acknowledgement}

The authors are thankful to Director, Regional Centre of Central Tuber Crops Research Institute, Bhubaneswar for extending the laboratory and land facility for carrying out the research work.

\section{References}

Chauhan T M, AliJ, Singh H, Singh N and Singh S P. 2014. Effect of Zinc and magnesium nutrition on yield, quality and removal of nutrients in wheat
(Triticum aestivum). Indian Journal of Agronomy, 59(2): 276-80.

Gupta V K. 1995. Zinc research and agricultural production. In:

Micronutrient Research and Agricultural Production, Tandon, H.L.S (Ed.). IBH \& Oxford Publishing Company, New Delhi, pp. 132-64.

Kabeerathumma S, Mohankumar B and Nair P G. 1987. Nutrient Uptake and Their Utilization by Yams, Aroides and Coleus. Technical Bulletin Series No.10, CTCRI, Thrivanthapuram, Kerala, India, 34 p.

Misra R S, NedunchezhiyanM, Shivalingaswamy $\mathrm{T} \mathrm{M}$ and Dison $\mathrm{S} \mathrm{E}$. 2002. Mass multiplication techniques for producing quality planting of Amorphophallus paeoniifolius (Dennst.) Nicolson (Araceae). Aroideana, 25: 7887.

Nair P G, C R Mohankumar and PSaraswathy. 1990. Effect of different levels of NPK on the growth and yield of Amorphophallus under upland condition in acid ultisol. In: National Symposium on Recent Advances in Tropical Tuber Crops. 7-9 November, 1990, Thiruvananthapuram, Kerala.

Nedunchezhiyan M. 2014. Crop architecture effects on elephant foot yam (Amorphophallus paeoniifolius) productivity and economics under rainfed conditions. Indian Journal of Agronomy, 59(1): 122-7.

Nedunchezhiyan M and Misra R S. 2008. Amorphophallus tubers invaded by Cynodondactylon. Aroideana, 31: 12933.

Nedunchezhiyan M, Mukherjee A, Byju G, Ravi V and George J. 2016. Growth, dry matter production and nutrient uptake of elephant foot yam (Amorphophallus paeoniifolius (Dennst.) Nicolson) as influenced by 
drip irrigation and fertigation levels. Journal of Root Crops, 42(1): 22-32.

Nedunchezhiyan M, Saurabh A and Ranasingh N. 2006. Elephant foot yam: A commercial crop for Orissa. Orissa Review, 63(1): 71-2.

Nedunchezhiyan M, Sinhababu DP and SahuP K. 2013. Effect of soil amendments and irrigation regimes on minimum tillage planted sweet potato (Ipomoea batatas) in rice (Oryza sativa) fallows under lowland conditions. Indian Journal Agricutural Sciences, 84(3): 371-75.

Nedunchezhiyan M, Byju G and Naskar SK. 2008. Yield potential and economics of elephant foot yam (Amorphophallus paeoniifolius) + green gram (Vigna radiata) intercropping system as influenced by mulching and fertilizer levels. Indian Journal Agricultural Sciences, 78(1): 17-20.

Nedunchezhiyan M, Misra RS and Shivalingaswamy TM. 2002. Elephant foot yam (Amorphophallus paeoniifolius (D.) Nicolson) as an intercrop in banana and papaya. Orissa Journal of Horticulture, 30(1): 80-2.

Nedunchezhiyan M, RaviV, ByjuGand George J. 2017. Organic source of nutrients effect on growth, yield and quality of elephant foot yam (Amorphophallus paeoniifolius). Indian
Journal of Agricultural Sciences, 87(8): 32-6.

Raghu A, Deepa V C and Sundaran K.1999. A study on soorana (Amorphophallus paeoniifolius), the king of the tubers. In: Tropical Tuber Crops in Food Security and Nutrition, Oxford and IBH Publishing Co. Pvt. Ltd. New Delhi, pp. 10-4.

Sahoo BM, Nedunchezhiyan M and Acharya P. 2014. Effects of organic and inorganic fertilizers on yield of elephant foot yam and soil enzymes activity. Journal of Root Crops, 40(2): 33-9.

Sahoo BM, Nedunchezhiyan M and Acharya P. 2015. Productivity potential of elephant foot yam (Amorphophallus paeoniifolius (Dennst.) Nicolson) in alfisols as influenced by fertility levels. The Bioscan, 10(3): 1255-7.

Sakal R and Singh AP. 1995. Boron research and agricultural production. In: Micronutrients Research and Agricultural Production, Tandon, H.L.S (Ed.). IBH \& Oxford Publishing Company, New Delhi.

Singh RN and Pathak RK. 2002. Effect of potassium and magnesium on yield, their uptake and quality characteristic of wheat (Triticum aestivum). Journal of Indian Society of Soil Science, 50: 1815.

\section{How to cite this article:}

Biswanath Sahoo, M. Nedunchezhiyan, P. Acharyya, R. Munshi, D. Sahu and Rojalin Pradhan. 2019. Effect of Secondary and Micronutrients on Growth Attributes and Yield of Elephant Foot Yam (Amorphophallus paeoniifolius). Int.J.Curr.Microbiol.App.Sci. 8(05): 323-330. doi: https://doi.org/10.20546/ijcmas.2019.805.037 